\title{
Trait Anxiety Index Among Students with Different Levels of Xenophobia
}

\author{
Elena Yu. Fedorenko, Tatiana V. Skutina, \\ Kseniya S. Kalinovskaya and Ekaterina V. Potapova* \\ Siberian Federal University \\ 79 Svobodny, Krasnoyarsk, 660041, Russia
}

Received 18.02.2017, received in revised form 04.12.2017, accepted 11.12.2017

In the article we discuss a problem of xenophobia among young people. In the case of increasing migration processes in Russia and the Krasnoyarsk Territory (Krai), we consider xenophobia to be the main framework of intolerant attitude to the "others", "aliens", or people of a different nationality. We paid special attention to the study of factors influencing xenophobic attitudes. These factors are: trait anxiety, tendency to frustration, rigidity, aggression.

Keywords: youth, xenophobia, trait anxiety, frustration, aggression, rigidity.

DOI: 10.17516/1997-1370-0179.

Research area: psychology.

The xenophobia problem has been one of the most challenging issues of Russian society. Researches of xenophobia are a dictate of the time. Caused by various reasons, migration flows grow stronger, making the problem of interaction between different cultures, races and ethnicities more and more acute. At the same time, there occur more cases of ethnically intolerant, aggressive and extremist behaviour. It brings up the question of the factors underlying such behaviour, that also include xenophobia.

Multiple researches including monitoring of tolerance and xenophobia (A.G. Asmolov, E.G. Lukovitskaia, G.L. Bardier, N.V. Kruglova, O.B. Skriabina) have stated that the least tolerant part of society, most vulnerable to xenophobic ideas, is the youth. Xenophobia is quite typical of the young people resident in small, ethnically homogenous towns, and, vice versa, in densely populated metropolises, where various forms of discrimination, social conflicts based on negative stereotypes, bias and repugnant enemy image are common (Kozlov, 2009). At the same time there is no doubt that the basis for xenophobic mindset establishes much earlier, in the school years. The research carried out by the authors in the years 2013-2014 clearly proved that one of the key factors of xenophobia is the person's intolerant attitude to his/her own self, which, due to the close genetic bond to the attitude towards others, causes interpersonal intolerance and xenophobia (Fedorenko et al., 2015).

In our turn, we rely on the concept of xenophobia as a "feeling of general aversion to

(C) Siberian Federal University. All rights reserved

* Corresponding author E-mail address: e.fedorenko@mail.ru; tvforte@mail.ru; kartashovaks@mail.ru; potapowa.catia2011@yandex.ru 
aliens and things connected to them, expressed in intolerant mindsets and actions, as well as hostility to tradition, culture and immigrants from other countries" (Fiore I, 2008). Just like tolerance/intolerance, xenophobia may be expressed to strangers from one's own cultural group, also perceived as aliens (Wahl, 2002). We understand xenophobic mindset as bias of hostile, aggressive, forbidding character towards people classified as aliens for these or those reasons; then xenophobia manifests itself as a problem of perception, and, particularly, as perception of differences of another as a basis for classifying him/her as an Alien.

In the present research we rely on the idea of the close interconnection between one's attitude to him/herself and the others (C. Rogers, J. Bugental et al.). In the works of Iurasova, E.N., and Dekhanova, I.A., the problem of xenophobia is closely associated with the problem of perception-assessment of one's own self and another person with the same personal characteristics, like self-esteem, self-attitude, self-image (Iurasova, Dekhanova, 2011). In the present time, it is extremely important to find the new determinants, that would explain the development of xenophobia. To our mind, one of such determinants is trait anxiety, for the roots of xenophobia grow from the mechanisms of anxiety, which is initially an emotion, not attached to a certain object. The object of fear (phobia) is usually the thing on which the anxiety gets shifted to at a certain moment. In other words, the ego shifts anxiety to an external object, preventing the "unwanted thoughts and senses from being realized". As xenophobia manifests itself in such emotions as hatred, intolerance and aversion, it makes sense to suggest that a xenophobic person may have such personal trait as aggressiveness. Frustration theory of neurosis claims that frustration experience may enhance anxiety and trigger psychological defense mechanisms including aggression. Aggression is often expressed in a xenophobic experience situation as a relatively stable personal trait described as one's readiness for aggressive behaviour, i.e. sequence of actions intended to cause physical or psychological harm, up to destruction of the object, another person or a group of people.

Within the framework of the present research, rigidness is understood as one's failure and unpreparedness for the planned behaviour pattern reconstruction under the circumstances when the previous pattern requires some significant changes. In this situation the degree, measure or level of the rigidness demonstrated by a person are directly connected not only to his individual psychological characteristics, but also to the specificity of the situation where such actions occur (degree of extremeness and danger of the situation of forced communication with people of other ethnicities and cultures).

Our research is focused on such age group as the youth, and, particularly, students aged from 17 to 21 . The hypothesis of the research is the following: students with high level of xenophobia shall also demonstrate higher level of trait anxiety. The research included a survey of 97 students of Krasnoyarsk colleges aged from 17 to 21, majoring in technical, engineering and economic subjects: 55 male and 42 female students. The respondents mostly identified themselves as representatives of Russian ethnicity, and a part of them, as Ukrainians, Belarusians, Evenki, and Khakass.

The authors used the following methods of research: at the first stage, xenophobia level assessment method of E.N. Iurasova, at the second stage, trait anxiety level assessment scale of Ch.D. Spielberg, Iu.L. Khanin, and at the third -psychic states assessment method (rigidness, frustration, aggression) of H.J. Eysenck.

According to the results of the first research stage, a sampling of respondents was divided into 


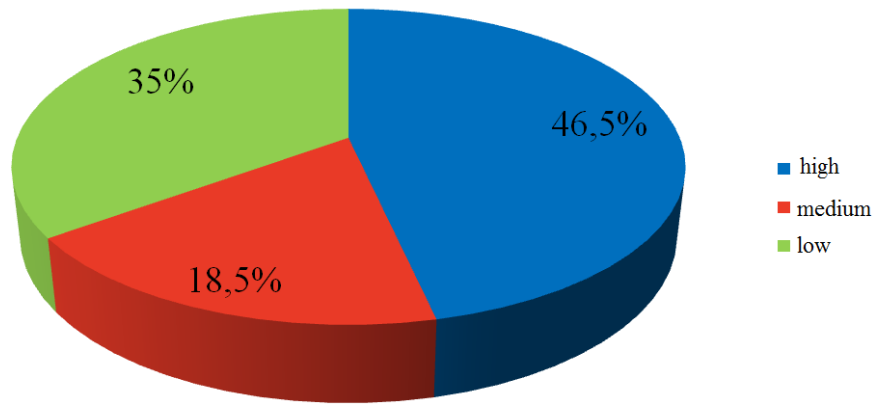

Fig. 1. Percentage distribution of respondents with different xenophobia levels

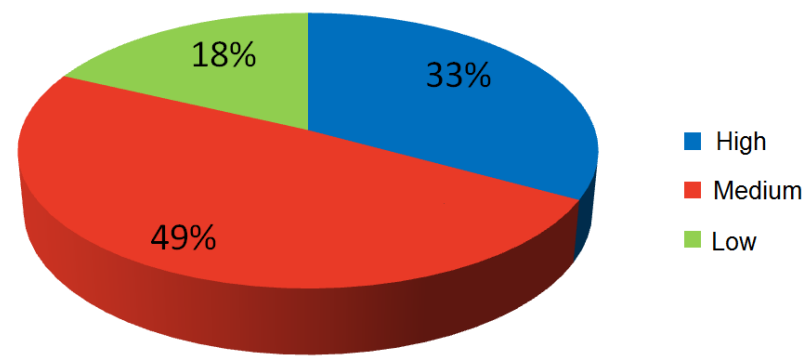

Fig. 2. Percentage distribution of respondents with different trait anxiety levels

three groups based on the level of xenophobia expression (high, medium, and low). Out of $100 \%, 46.5 \%$ of respondents showed high level, $18.5 \%$ showed medium level and $35 \%$ showed low level of xenophobia (see Fig. 1). For our research, it was relevant to focus on the respondents with high and low levels of xenophobia.

At the second stage of the research, trait anxiety assessment scale of Ch.D. Spielberg and Iu.L. Khanin was used to find out that $33 \%$ of students have high level of trait anxiety, $49 \%$ have medium level, and $18 \%$ of the respondents have low level of trait anxiety (Fig. 2).

The analysis of the respondents' personal data carried out during the first two stages revealed that out of the total number of respondents with high level of trait anxiety, $54 \%$ showed high level of xenophobia and $18 \%$ showed low level. In the group with low level of trait anxiety, $27 \%$ of the respondents demonstrated low level of xenophobia and $12 \%$ of them showed high level. Figure 3 illustrates the correlation between xenophobia and trait anxiety levels in the studied sampling of respondents.

At the third stage, the authors searched for such stable psychic conditions as: frustration, aggression, rigidity, both typical of the respondents and their correlation with the trait anxiety and xenophobia levels. Further, it was attempted to compare groups of respondents with high and low xenophobia levels with regard to four personal characteristics: trait anxiety, frustration, aggression, rigidity (Fig. 4-5).

Figure 4 proves that in the group of respondents with low level of xenophobia, medium level of trait anxiety (55\%) and frustration (64\%) prevail along with the medium and low levels of aggression (48\% and $49 \%$ ) and frustration (49\% and $46 \%$ ). High level of the studied indicators is hardly found.

Figure 6-7 demonstrates that in the group of respondents with high level of xenophobia high level of trait anxiety (54\%) prevails, along with medium levels of frustration (56\%), aggression 


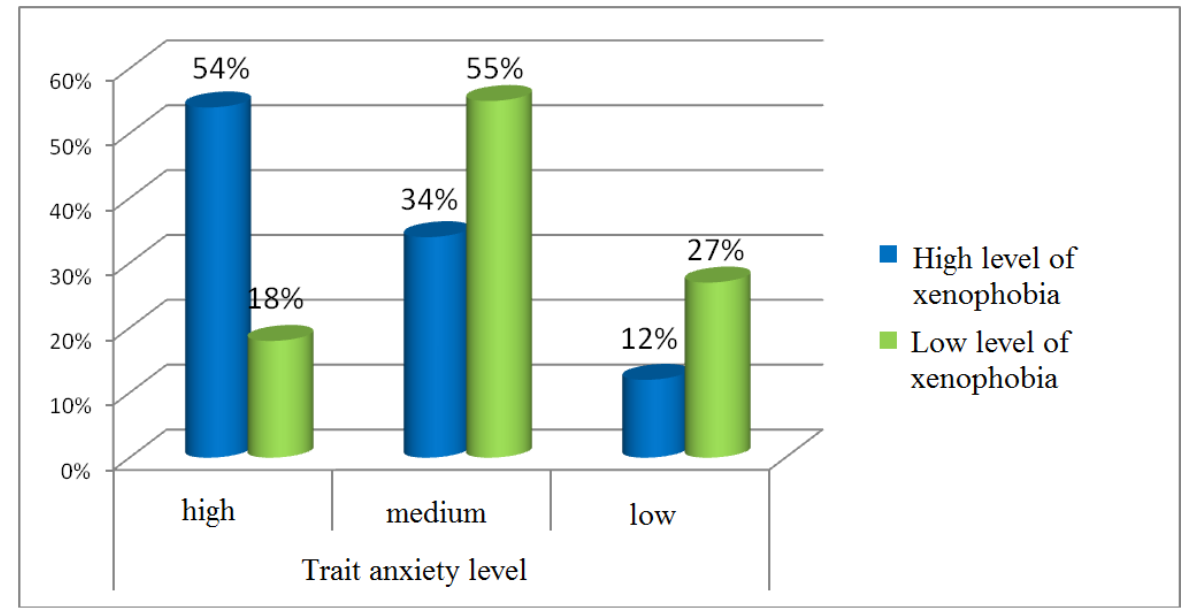

Fig. 3. Percentage distribution of trait anxiety levels amount respondents with high and low xenophobia levels

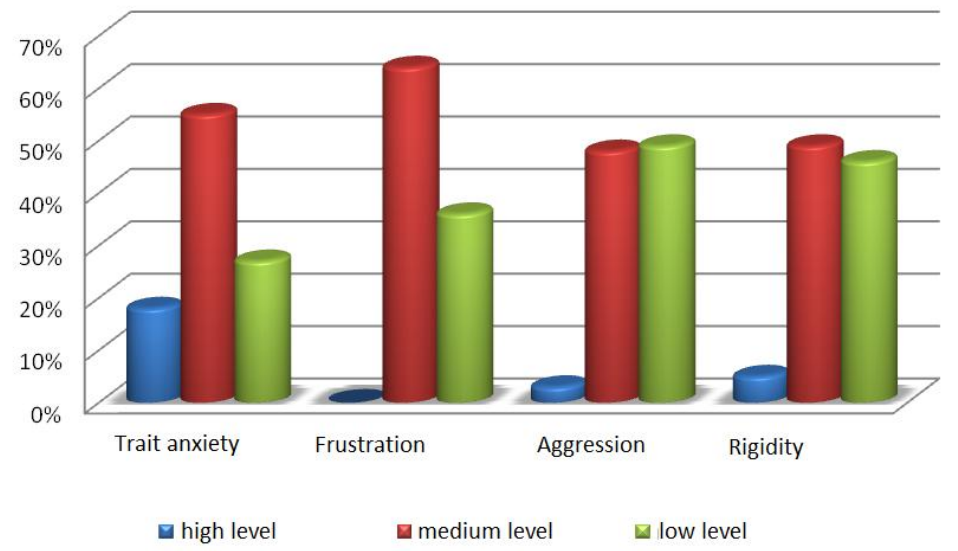

Fig. 4. Bar chart of percentage distribution of trait anxiety, frustration, aggression and rigidity indications in the group of respondents with low level of xenophobia

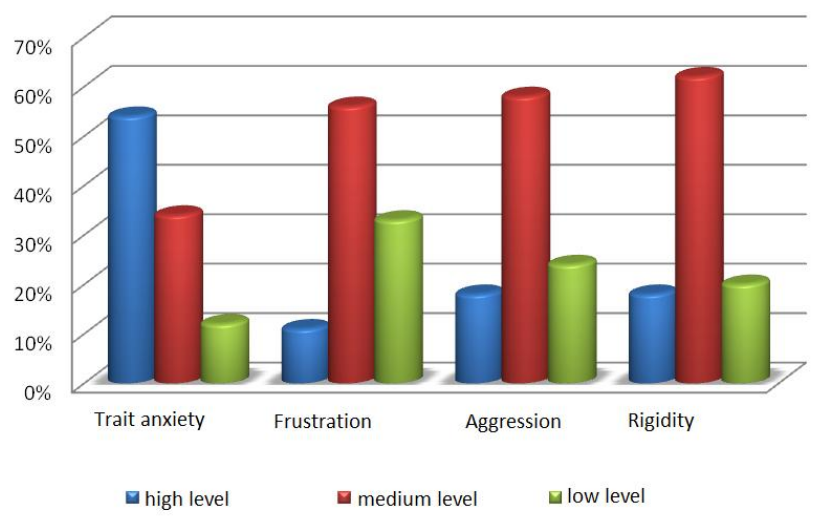

Fig. 5. Bar chart of percentage distribution of trait anxiety and self-assessment of psychic conditions in the group of respondents with high level of xenophobia 


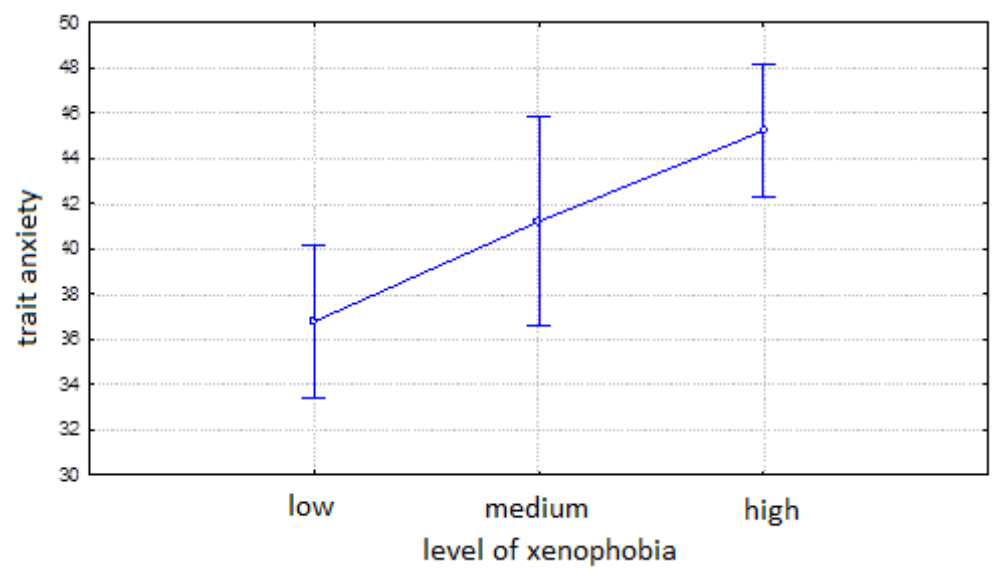

Fig. 6. Xenophobia level influence on intensity of trait anxiety

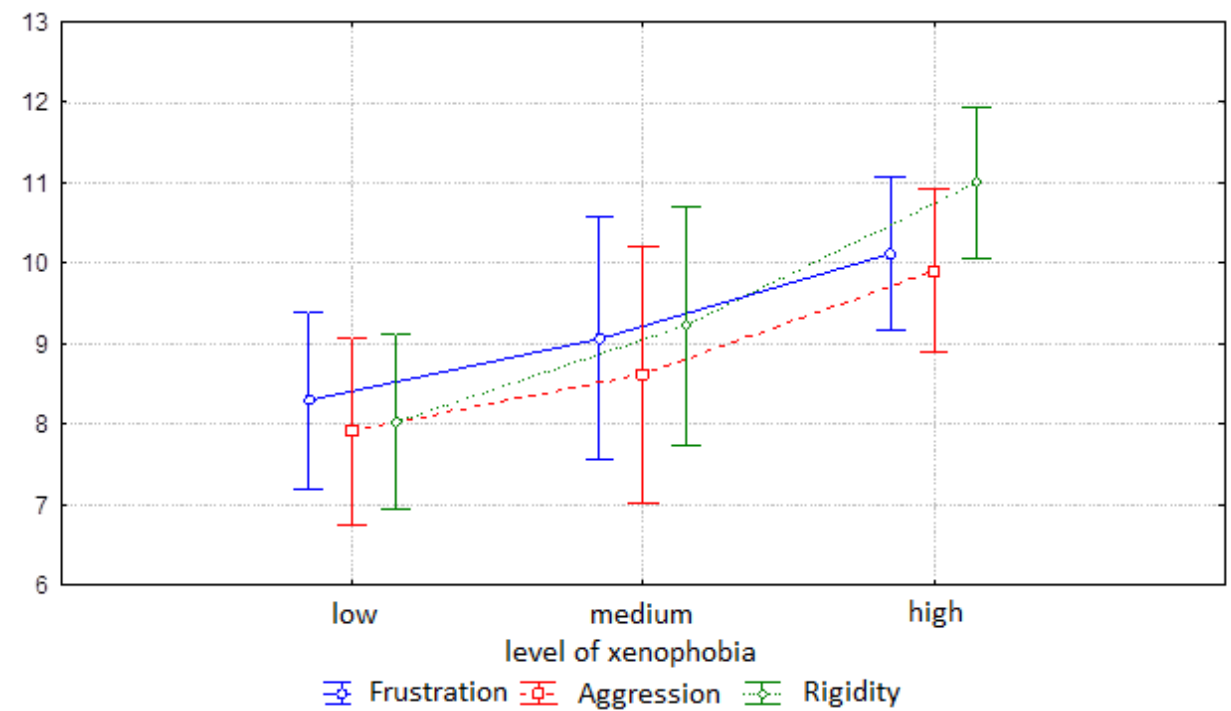

Fig. 7. Xenophobia level influence on intensity of frustration, aggression, and rigidity

(58 \%), and frustration (62\%). Despite the dominance of the medium levels, the frequency of high level occurrence is in between 11-18 \%.

The comparative study of respondents with low and high levels of xenophobia, carried out with F-test based on the frequency of occurrence of distinctive trait anxiety and frustration, aggression, and rigidity, stated that high level of trait anxiety $(\varphi=3.42$ at $p=0.001)$, aggression $(\varphi=2.99$ at $p=0.003)$, frustration $(\varphi=2.34$ at $p=0.01)$ and rigidity $(\varphi=1.88$ at $p=0.04$ ) occurs much more frequently among respondents with high level of xenophobia. At the same time, low and medium levels of trait anxiety $(\varphi=1.88$ at $p=0.04$ and $\varphi=1.7$ at $\mathrm{p}=0.04)$, low level of aggression $(\varphi=2.33$ at $\mathrm{p}=0.01)$ and rigidity $(\varphi=2.49$ at $\mathrm{p}=0.009)$ occur much more frequently among respondents with low level of xenophobia.

\section{Variance analysis bar charts}

The results of the statistic survey may be used as a basis for describing emotional and personal characteristics of the respondents with high and low levels of xenophobia. Thus, 
respondents with low level of xenophobia generally demonstrate low and medium levels of trait anxiety, low levels of frustration, aggression, and rigidity, while respondents with high level of xenophobia are normally characterized with a high level of trait anxiety, aggression, frustration, and rigidity. Summarizing the aforesaid, we may claim to have found significant interconnection of xenophobia and such personal characteristics as trait anxiety, frustration, rigidity, and aggression. The obtained data open opportunities for further search for the ways of preventing xenophobia and intolerance to aliens, including people of other ethnicities, in the situation of dynamic migration processes and growing prospects of living in a consolidating multicultural society.

\title{
References
}

Fedorenko, E.Iu., Skutina, T.V., Kalinovskaia, K.S., Potapova, E.V.(2015). Sviaz'ksenofobicheskikh tendentsiy, kommunikativnoy tolerantnosti i samootnosheniia v podrostkovom vozraste [Connection of xenophobic tendencies, communicative tolerance and self-attitude in adolescence], In Psikhologiia obucheniia [Psychology of teaching], 2, 69-86.

Fiore I. The psychological dynamics that make people xenophobic. (2008). In Rivista di psicologia clinica: Teoria e metodi dell'intervento, 3, 251-274.

Iurasova, E.N., Dekhanova, I.A. (2011). Lichnostnye osobennosti i predraspolozhennost' $\mathrm{k}$ ksenofobii [Personal traits and inclination for xenophobia], In Tolerantnost' $v$ sovremennom obschestve: opyt mezhdistsiplinarnykh issledovaniy [Tolerance in modern society: interdisciplinary research experience], collection of articles of I International Scientific and Practical Conference of December 1-2, Yaroslavl.

Kozlov, A. et al. (2009). Ksenofobiia v molodiozhnoy srede: Doklad po rezul'tatam K86 monitoringa [Xenophobia in the youth medium: Report on the results of K86 monitoring]. Moscow: Moskovskaia Khel'sinskaia gruppa. 114 p.

Soldatova, G.U., Makarchuk, A.V. (2006). Mozhet li drugoy stat' drugom? Trening po profilaktike ksenofobii [May an alien become a friend? Xenophobia prevention training]. Moscow: Genesis.

Wahl, K. (2002). Development of Xenophobia and Aggression. In International Journal of Comparative and Applied Criminal Justice, 26 (2), 247-256.

\section{Показатели личностной тревожности у студентов с разным уровнем ксенофобии}

\author{
Е.Ю. Федоренко, Т.В. Скутина, \\ К.С. Калиновская, Е.В. Потапова \\ Сибирский федеральный университет
} Россия, 660041, Красноярск, пр. Свободный, 79

В представленных материалах обсуждается проблема проявления ксенофобии среди молодежи как основы интолерантного отношения к другому, незнакомому, или представителю другой начиональности в контексте усиления миграционных процессов в России и Красноярском крае. Особое внимание в статье уделяется исследованию факторов, так или иначе связанных 
с ксенофобическими установками или лежащих в их основе. В качестве таких факторов рассматриваются личностная тревожность, склонность к фрустрации, ригидность, агрессия.

Ключевые слова: молодежь, ксенофобия, личностная тревожность, фрустрация, агрессия, ригидность.

Научная специальность: 19.00.00 - психологические науки. 